\title{
MENGANTISIPASI KEJAHATAN SEKSUAL TERHADAP ANAK MELALUI PEMBELAJARAN "AKU ANAK BERANI MELINDUNGI DIRI SENDIRI": Studi di Yayasan al-Hikmah Grobogan
}

\author{
Siti Hikmah \\ Madrasah Ibtidaiyah (MI) al-Hikmah Grobogan \\ e-mail: mialhikmah2015@yahoo.co.id
}

\begin{abstract}
Abstrak
Recently, the sexual crime for children tends to increase significantly and it causes a traumatic impact on the victims. So it needs strong effort to anticipate the sexual crimes for children as early as possible. This paper describes the efforts to anticipate sexual abuse for children through learning method namely "I dare to take care of myself" at al-Hikmah Foundation, Grobogan. The method used was qualitative descriptive and field research by conducting Focus Group Discussion (FGD). The researcher used interviews and documentation technique for data collection. The teachers and students of alHikmah foundation Grobogan became the sources of primary data. While the secondary data sources were taken from a literature review that is relevant to this study. The result showed that one of the efforts to anticipate sexual abuse for children was by optimizing the teachers' role and parents through Focus Group Discussion activities. Indeed, it was found ten themes to motivate children defending themselves, namely: Why different?, Where the baby came out?, Where to pee?, What kind of touch is it?, Do I tell you or not?, I'm afraid of ghost, Who is he?, Circumcision, Why is it not allowed?, Who could protect me? These activities would produce an understanding of the importance of taking care of themselves to avoid sexual crimes for children and parents.
\end{abstract}

Kejahatan seksual anak dari tahun ke tahun semakin meningkat, dan menyebabkan dampak traumatis terhadap korban. Maka diperlukan upaya untuk mengantisipasi kejahatan seksual pada anak sedini. Tulisan ini menjelaskan mengenai upaua mengantisipasi kejahatan seksual anak melalui pembelajaran aku anak berani melindungi diri sendiri di Yayasan al-Hikmah Grobogan. metode yang digunakan adalah kualitatif deskriptif, jenis field research, dengan Focus Group Discussion (FGD). Teknik pengumpulan data menggunakan wawancara dan dokumentasi. Sumber data primer adalah guru kelas dan siswa Ml Yayasan al-Hikmah Grobogan. 
Sumber data sekunder adalah kajian pustaka dan literature review yang relevan dengan kajian ini. Upaya yang dapat dilakukan untuk mengantisipasi kejahatan seksual anak dilakukan dengan optimalisasi peran guru kelas dan orang tua siswa melalui kegiatan FGD. Mengantisipasi kejahatan seksual pada anak dilakukan melalui pembelajaran aku anak berani melindungi diri sendiri melalui sepuluh tema yaitu: kenapa berbeda, dari mana keluarnya adik bayi, pipis dimana, sentuhan apa nih, cerita nggak ya, ih takut ada hantu, siapa itu, khitan, mengapa tidak boleh, siapa yang bisa melindungiku. Kegiatan ini menghasilkan pemahaman kepada anak dan orang tua pentingnya menjaga diri sendiri agar terhindar dari kejahatan seksual.

Kata Kunci: kejahatan seksual terhadap anak; pembelajaran "aku anak berani melindungi diri sendiri"

\section{A. Pendahuluan}

Maraknya kasus kejahatan seksual di masyarakat menimbulkan kesesahan yang begitu luar biasa. Beberapa kasus kejahatan seksual yang hangat diperbincangkan seperti kasus pedofilia yang ramai disorot media di Jakarta International School (JIS), sekolah yang dihuni oleh masyarakat kelas atas, ternyata didalamnya terdapat kasus keeahatan seksual pada anak-anak di bawah umur. Tidak hanya di Jakarta, kasus serupa juga menimpa 11 pelajar di Medan, yang dilakukan oleh gurunya yang merupakan warga negara Singapura ${ }^{1}$. Di Tenggarong, Kalimantan Timur, seorang guru melakukan sodomi kepada muridnya ${ }^{2}$. Kasus lain mengenai kejahatan seksual terjadi pada kasus pedofilia disertai kasus pembunuhan dan mutilasi menimpa empat belas anak jalanan di Jakarta. Pelakunya adalah Babe Baikuni yang dikenal dengan sebutan Babe. ${ }^{3}$

Menurut data Komnas Perlindungan Anak pada tahun 2010 telah diterima laporan kekerasan pada anak mencapai 2.046 kasus, laporan kekerasan pada

1John Obrak, "Pedofilia di Jakarta International School-JIS termasuk Kejahatan Kemanusiaan", dalam laman Kompasiana, http://www.kompasiana.com/yungobrak/pedofiliadi-jakartainternationalschool-jis-termasuk-kejahatan-kemanusiaan-

2_54f79481a33311207e8b467c; diakses 15 April 2016; Nibras Nada Nailufar, "Tersangka Pedofil di Facebook Cabuli 11 Anak, Termasuk Keponakannya" dalam laman http:// megapolitan.kompas.com/read/2017/03/17/18003001/tersangka.pedofil.di.facebook.

cabuli.11.anak.termasuk.keponakannya, diakses 23 April 2016.

2“Peristiwa Kejahatan Seksual Anak”, www.merdeka.com, diakses 19 Pebruari 2016

${ }^{3}$ Nibras Nada Nailufar, "Cabuli Anak-anak, Pedagang Pasar Malam Berusia 60 Tahun Ditangkap", www.kompas.com, diakses 23 Maret 2016 
tahun 2011 naik menjadi 2.462 kasus, pada tahun 2012 naik lagi menjadi 2.629 kasus dan melonjak tinggi pada tahun 2013 tercatat ada 1.032 kasus kekerasan pada anak yang terdiri dari: kekerasan fisik 290 kasus (28\%), kekerasan psikis 207 (20\%), kekerasan seksual 535 kasus (52\%). Sedangkan dalam tiga bulan pertama pada tahun 2014 ini, Komnas perlindungan anak telah menerima 252 laporan kekerasan pada anak, yang didominasi oleh kejahatan seksual dari tahun 20102014 yang berkisar $42-62 \%{ }^{4}$.

Kejahatan seksual terhadap anak adalah suatu bentuk penyiksaan anak di mana orang dewasa atau remaja yang lebih tua menggunakan anak untuk rangsangan seksual. Ketua Komisi Nasional Perlindungan Anak, Arist Merdeka Sirait mengatakan kejahatan seksual yang terjadi saat ini sedang mengancam dunia anak, situasi kejahatan seksual terhadap anak sudah sangat darurat. ${ }^{5}$ Kejahatan seksual, tidak hanya terjadi di luar rumah tetapi ada juga yang terjadi di dalam rumah di mana predatornya adalah orang tua kandung, paman, kakak dan juga orang tua tiri.

Kejahatan seksual anak memiliki dampak traumatik yang dialami anak korban kekerasan seksual begitu mendalam dan sulit untuk disembuhkan. Trauma psiologi pada anak yang menjadi korban kejahatan seksual sulit dihilangkan dari ingatan anak, terutama jika pelaku masih berada dan tinggal tidak jauh dari lingkungan anak. Dengan kondisi tersebut, orang tua menjadi sangat kawatir dan was-was terhadap keselamatan mereka, apalagi jika jauh dari anak seperti saat bermain di luar bersama kawan-kawannya atau saat ditinggal dirumah tanpa ibu atau keluarga. Bahkan anggapan sekolah adalah tempat aman bagi anak tak sepenuhnya benar, karena banyak kasus kejahatan seksual anak, pelakunya adalah guru, pegawai sekolah, atau teman sekolah.

Mendasarkan pada hal tersebut, perlu upaya untuk mencegah dan melindungi anak dari ancaman kejahatan seksual di lingkungannya. Salah satunya dengan memberikan pendidikan seks kepada anak sejak dini. Idelanya pendidikan seksualitas harus dimulai dari keluarga, karena orang tua adalah orang pertama dan utama yang bertanggung jawab terhadap pertumbuhan dan perkembangan anak. Namun sebagian besar orang tua belum mempunyai

${ }^{4}$ Www.kompas.com, diakses 23 Maret 2016

${ }^{5}$ Harian Suara Merdeka, dalam www.suara merdeka, diakses 23 Maret 2016. 
pengetahuan cukup atau tidak mempunyai kemampuan untuk menyampaikan pemahaman kepada anak. ${ }^{6}$ kepada anaknya maka tugas tersebut diambil sekolah menjadi pilihan agar tidak banyak anak menjadi korban kejahatan seksual yang terjadi setiap saat melalui pembelajaran yang "ramah anak" artinya yang sesuai dengan usia perkembangan anak dengan bahasa yang bisa difahami anak dan media yang memudahkan anak untuk terus mengingat pentingnya materi tersebut.

Pembelajaran "aku anak yang berani, bisa melindungi diri sendiri" menjadi pilihan dalam mengenalkan akan pentingnya anak mengenali dirinya, menjaga dirinya, yang dapat memotivasi anak untuk bisa menjadi anak yang berani, yang dapat melindungi dirinya sendiri dari orang yang akan melakukan kejahatan seksual pada dirinya.

\section{B. Bentuk-bentuk Kejahatan Seksual Anak}

Kejahatan seksual (sexual abuse) merupakan jenis penganiayaan yang biasanya dibagi dalam kategori berdasar identitas pelaku terdiri dari familial Abuse dan extrafamilial abuse. ${ }^{7}$ Familial Abuse menurut Mayer dalam Tower yaitu kejahatan seksual yang dilakukan oleh anggota keluarga, family abuse disebut Incest, sexual abuse yang masih dalam hubungan darah, menjadi bagian dalam keluarga inti. Seseorang yang menjadi pengganti orang tua, misalnya ayah tiri, atau kekasih, termasuk dalam pengertian incest. Kategori incest dalam keluarga dan mengaitkan dengan kejahatan seksual pada anak. Kategori pertama, sexual molestation (penganiayaan). Hal ini meliputi interaksi noncoitus, petting, fondling, exhibitionism, dan voyeurism, semua hal yang berkaitan untuk menstimulasi pelaku secara seksual. Kategori kedua, sexual assault (perkosaan), berupa oral atau hubungan dengan alat kelamin, masturbasi, fellatio (stimulasi oral pada penis), dan cunnilingus (stimulasi oral pada klitoris). Kategori terakhir yang paling fatal disebut forcible rape (perkosaan secara paksa), meliputi kontak seksual. Rasa takut, kekerasan, dan ancaman menjadi sulit bagi korban. Mayer mengatakan bahwa dua kategori terakhir di atas yang paling banyak menimbulkan trauma terberat

${ }^{6}$ Hasyim Hasanah, "Pemahaman Kesehatan Reproduksi Bagi Perempuan: Sebuah Strategi Mencegah Berbagai Resiko Masalah Kesehatan Reproduksi Remaja", SAWWA, Jurnal Studi Gender, Vol. 11, No. 2, 2016, h. 244.

${ }^{7}$ Cynthia Crosson Tower, Child Abuse and Neglect, (USA: Mc.Graw Hill, 2002), h. 27. 
bagi anak-anak. Derajat trauma tergantung pada tipe dari kekerasan seksual, korban dan survivor mengalami hal yang sangat berbeda. Survivor yang mengalami perkosaan mungkin mengalami hal yang berbeda dibanding korban yang diperkosa secara paksa. ${ }^{8}$

Extrafamilial Abuse dilakukan oleh orang lain di luar keluarga korban, dan hanya $40 \%$ yang melaporkan peristiwa kekerasan. Kekerasan seksual yang dilakukan oleh orang dewasa disebut pedophile, yang menjadi korban utamanya adalah anak-anak. Pedophilia diartikan "menyukai anak-anak" Pedetrasy merupakan hubungan seksual antara pria dewasa dengan anak laki-laki. ${ }^{9}$ Pornografi anak menggunakan anak-anak sebagai sarana untuk menghasilkan gambar, foto, slide, majalah, dan buku. Biasanya ada tahapan yang terlihat dalam melakukan kejahatan seksual, pelaku mencoba perilaku untuk mengukur kenyamanan korban. Jika korban menuruti, kejahatan akan berlanjut dan intensif, berupa: nudity (dilakukan oleh orang dewasa), disrobing (orang dewasa membuka pakaian di depan anak), genital exposure (dilakukan oleh orang dewasa), observation of the child (saat mandi, telanjang, dan saat membuang air), Mencium anak yang memakai pakaian dalam, fondling (meraba-raba dada korban, alat genital, paha, dan bokong), Masturbasi, fellatio (stimulasi pada penis, korban atau pelaku sendiri), cunnilingus (stimulasi pada vulva atau area vagina, pada korban atau pelaku), digital penetration (pada anus atau rectum), penile penetration (pada vagina), Digital penetration (pada vagina), penile penetration (pada anus atau rectum), dry intercourse (mengelus-elus penis pelaku atau area genital lainnya, paha, atau bokong korban). ${ }^{10}$

${ }^{8}$ Mayer dalam Cynthia Crosson Tower, Child Abuse, h. 33; John Stucke, Early Trauma Tied to Adult Problem, (Business New, online) dalam http://www.proquest.com/pqdauto," diakses 21 Januari 2017.

${ }^{9}$ Cynthia Crosson Tower, Child Abuse, h. 38.

${ }^{10}$ Cynthia Crosson Tower, Child Abuse, h. 39-40; Gemma-Gladstone B.A., et.al., Characteristics of Depressed Patients Who Report Childhood Sexual Abuse. (Am.J. Phychiat, 1999), h. 156; Husain. S.A. Canwell. D.P. "Physical and Sexual Abuse of Children". Chapter 6. Special Problem in Fundamental of Child and Addoscent Psychopathology, (American Psychiatric Press inc. Washington D.C. 1991), h. 46; H.I. Kaplan, Sadock, B.J., Grebb. J.A., Problem Related to Abuse or Neglect in Kaplan and Sadock's Synopsis of Psychiatry Behavior Sciences Clinical Psychiatry, (USA: William \& Wilkins. Baltimore, 1994), h. 211. 


\section{Faktor Penyebab Terjadinya Kejahatan Seksual pada Anak}

Ada beberapa penyebab terjadinya perilaku kejahatan seksual pada anak. ${ }^{11}$ Pertama, pornoaksi dan pornografi yang tidak terkendali. Kecanggihan dan kian murahnya beragam gadged membuat siapa saja mudah mendapatkan konten pornografi sebanyak-banyaknya. Bukan sembarang pornografi, tetapi konten pornografi yang makin brutal dampaknya bisa ditebak, pelaku menjadi porn addict dan akhirnya mencari pelampiasan. Termasuk menjadikan anak kecil sebagai objek seksual. Korban yang paling mudah disasar adalah anak kecil. Mereka mudah dibujuk, diancam, atau dibunuh sekalian. Kedua, rangsangan seksual bukan saja dari konten pornografi tetapi dari penampilan banyak perempuan yang senang memakai busana minim dan ketat, pria dewasa normal akan terangsang dan sebagian dari mereka akan mencari pelampiasan hasrat seksualnya. Lagi-lagi, korban yang paling gampang disasar adalah anak-anak. Ketiga, keteledoran orang tua memberikan pakaian minim kepada anak-anak perempuan. Banyak bocah anak perempuan didandani dengan pakaian tanktop, rok mini, dan sebagainya. Ini menimbulkan godaan bagi kaum pedofil untuk menyasar mereka. Orang tua harusnya memberikan pakaian yang wajar, lebih baik lagi menutup aurat kepada anak baik laki-laki atau perempuan sekalipun mereka belum baligh, dewasa. Menanamkan rasa malu harus ditanamkan kepada anak sejak dini. Misalnya, mereka harus memahami untuk tidak membiasakan diri walau masih kecil bertelanjang didepan orang lain, ketika keluar dari kamar mandi, berganti pakaian, dan sebagainya. Kepada anak perempuan juga ditanamkan sejak kecil untuk berbusana muslimah. Menutup aurat disampaikan sebagai bagian dari hukum syariat yang harus dipatuhi baik bagi laki-laki maupun perempuan seperti QS. al-Nur [24]:31, QS. al-Ahzab [33]: 59 dan beberapa hadits tentang kewajiban menutup aurat dan cara berpakaian.

Keempat, orang tua lengah dalam mengawasi lingkungan pergaulan anak, terutama untuk anak-anak yang kedua orang tuanya sama-sama bekerja. Orang tua tidak membekali anak etika pergaulan, sekalipun masih kanak-kanak, orang tua sudah semestinya mengajarkan rasa malu bila aurat mereka terlihat, diajarkan dimana tempat membuka pakaian, larangan mencium dan dicium lawan jenis, termasuk berani bercerita bila ada orang yang berani memegang

\footnotetext{
${ }^{11}$ Eric From, Akar Kekerasan, (Yogyakarta: Pustaka Pelajar, 1997), h. 37.
} 
organ kelamin mereka. Kelima, anak tidak dibekali dengan pengetahuan dan keterampilan yang dapat melindungi dirinya dari ancaman kejahatan seksual.

\section{Dampak Kejahatan Seksual bagi Perkembangan Anak}

Lenore Terr menggambarkan bagaimana efek trauma pada anak dapat memicu perilaku amoral anak sebagai bentuk perlawanan akan tindakan tidak menyenangkan yang telah dialaminya. Lenore Terr yang juga berlatar belakang sebagai psikiater handal dari Michigan University tersebut menjelaskan bahwa efek trauma itu muncul sebagai akibat dari ketidakmampuan anak dalam melakukan perlawanan terhadap pihak yang telah melakukan tindakan yang tidak menyenangkan terhadapnya. ${ }^{12}$ Hal ini mengarah pada munculnya konflik dan pergulatan batin di dalam ranah kesadaran anak sebagai bentuk sikap tidak menerima perlakuan buruk yang dialaminya yang pada akhirnya mendorong anak untuk mengekspresikan apa yang dirasakan.

Efek trauma ini akan melekat kuat pada memori anak yang terus menerus muncul dalam ingatan anak secara tiba-tiba, baik melalui stimulus penglihatan dan pendengaran, secara langsung maupun tidak langsung. Sehingga dengan sedikit stimulasi pada traumanya, anak akan dengan mudah terpantik untuk melakukan tindakan agresif, kekerasan, termasuk perilaku amoral. Hal tersebut merupakan coping strategy anak dalam mengatasi konflik batin yang disebabkan oleh trauma. ${ }^{13}$

Pada fase ini, apabila anak sudah terpapar oleh faktor stimulus seperti media yang bernuansa seksual, maka seorang anak akan cenderung mengalami gejolak batin untuk mengekspresikan perilaku dan orientasi seksualnya. Jika pihak keluarga dan lingkungan sosial tidak memberikan pengawasan dan pengarahan yang tepat, maka seorang anak akan mendapatkan angin segar untuk mempraktekkan apa yang seolah diketahuinya dari tayangan pornografi tersebut. Fatalnya, perilaku seksual mereka seringkali dilakukan kepada anak yang pada umumnya berusia lebih muda dari mereka dengan maksud untuk

\footnotetext{
${ }^{12}$ Lenore C. Terr, Too Scared to Cry: Psychic Trauma in Childhood, (New York: Basic Books, 1990), https://www.goodreads.com/book/show/787568.Too_Scared_To_Cry, h. 372, diakses 12 Januari 2017.

${ }^{13}$ Richard E Heyman \& Amy MS. Slep, "Do Child Abuse and Intraparental Marriage and Violence Lead to Adultthood Family Violence?", Journal of Mirrage and Family, 4, h. 867870, dalam http://www.proquesr.com/pqdauto, diakses 27 Januari 2017
} 
menekan tingkat perlawanan saat aksi kejahatan seksual dilakukan. Dengan alasan inilah, media pornografi dinilai benar-benar berdampak sangat destruktif terhadap perkembangan mental dan perilaku anak.

Dampak trauma akibat kejahatan seksual menurut psychological disorder gangguan stress pasca trauma "post traumatic stres disorder" (PTSD)) simptomnya berupa ketakutan, kecemasan, emosional, menutup diri, mengisolasi diri, krisis identitas. Kondisi traumatik mempengaruhi sikap, cara pandang, orientasi seksual dan memicu munculnya perilaku amoral sebagai bentuk perlawanan terhadap perlakuan tidak menyenangkan yg dialami anak yaitu penghianatan, trauma seksual, merasa tidak berdaya, stigma merasa berdosa dan bersalah. Betrayal (penghianatan) merupakan bentuk kepribadian yang harus dihilangkan dari perasaan anak atas kepercayaan yang telah dibangun anak. Dasar utama bagi korban kejahatan seksual adalah penghianatan kepercayaan anak dan otoritas orang tua yang telah dibangun dengan pondasi kuat. Traumatic sexualzation (trauma secara seksual). Russel (dalam Tower, 2002) menemukan bahwa perempuan yang mengalami kejahatan seksual cenderung menolak hubungan seksual, dan sebagai konsekuensinya menjadi korban kekerasan seksual dalam rumah tangga, korban lebih memilih pasangan sesama jenis, dan lain-lain. Powerlessness (merasa tidak berdaya), rasa takut menembus kehidupan korban, mimpi buruk, fobia, dan kecemasan dialami korban disertai dengan rasa sakit. Perasaan tidak berdaya mengakibatkan individu merasa lemah. Korban merasa dirinya tidak mampu dan kurang efektif dalam bekerja. Beberapa korban juga merasa sakit pada tubuhnya. Sebaliknya, pada korban lain memiliki intensitas dan dorongan yang berlebihan dalam dirinya. ${ }^{14}$ Rasa takut, mimpi buruk, phobia, cemas disertai rasa sakit. Perasaan tidak berdaya mengakibatkan individu merasa lemah, tidak mampu dan kurang efektif dalam bekerja. Stigmatization, korban kejahatan seksual umumnya merasa bersalah, malu, memiliki gambaran diri yang buruk. Rasa bersalah dan malu terbentuk akibat ketidakberdayaan dan merasa bahwa mereka tidak memiliki kekuatan untuk mengontrol dirinya. Korban sering merasa berbeda dengan orang lain, dan beberapa korban marah pada tubuhnya akibat penganiayaan yang dialami. Korban lainnya menggunakan obat-obatan dan minuman alkohol untuk meng-

${ }^{14}$ Cynthia Crosson Tower, Child Abuse, h. 42. 
hukum tubuhnya, menumpulkan inderanya, atau berusaha menghindari memori kejadian tersebut. ${ }^{15}$

Menurut Sitohang (2004) anak yang mengalami kejahatan seksual, dalam jangka pendek akan mengalami mengalami mimpi-mimpi buruk, ketakutan yang berlebihan pada orang lain, dan konsentrasi menurun yang akhirnya akan berdampak pada kesehatan. Untuk jangka panjangnya, ketika dewasa nanti dia akan mengalami fobia pada hubungan seks. Bahkan bisa terjadi dampak yang lebih parah, dia akan terbiasa dengan kekerasan sebelum melakukan hubungan seksual. ${ }^{16}$

Bisa juga setelah menjadi dewasa, anak tersebut akan mengikuti apa yang dilakukan kepadanya semasa kecilnya serta depresi, gangguan stress pasca trauma, kegelisahan, kecenderungan untuk menjadi korban lebih lanjut pada masa dewasa, dan dan cedera fisik untuk anak di antara masalah lainnya. Pelecehan seksual oleh anggota keluarga adalah bentuk inses, dan dapat menghasilkan dampak yang lebih serius dan trauma psikologis jangka panjang, terutama dalam kasus inses orang tua, sex disorder, gangguan rahim, HIV/AIDS dan gangguan seksual lainnya.

Menurut Mulyadi korban kejahatan seksual masih merasa dendam terhadap pelaku, takut menikah, merasa rendah diri, dan trauma akibat eksploitasi seksual, meski kini mereka sudah dewasa atau bahkan sudah menikah. Bahkan eksploitasi seksual yang dialami semasa masih anak-anak banyak ditengarai sebagai penyebab keterlibatan dalam prostitusi. ${ }^{17}$ Jika kejahatan seksual terjadi pada anak yang masih kecil mempunyai pengaruh buruk yang ditimbulkan antara lain dari yang biasanya tidak mengompol jadi mengompol, mudah merasa takut, perubahan pola tidur, kecemasan tidak beralasan, atau bahkan simptom fisik seperti sakit perut atau adanya masalah kulit, dan lain-lain. ${ }^{18}$ Dampak lain yang dapat terjadi adalah ${ }^{19}$ Anak berbohong, ketakutan, kurang dapat mengenal cinta atau kasih sayang, sulit percaya dengan orang lain; Harga diri anak

${ }^{15}$ Ibid., h. 43.

${ }^{16}$ Terry and Belkin, Child Psycology, (Newyork: McGraw-Hills, 1989), h. 228.

${ }^{17}$ R. Mulyadi, Kenali rasa Cemas yang Tidak Rasional, 2003, h. 2, dalam www.sinarharapan.com, diakses 27 Januari 2017

${ }^{18}$ A. Nadia, "Penganiayaan terhadap Anak dalam Keluarga", Makalah Seminar Kekerasan Anak: Efek Psikis, Fisik, dan Tinjauan Agama, 13-19 September 2004, h. 12.

${ }^{19} \mathrm{Ibid} ., \mathrm{h} .13$. 
rendah dan menunjukkan perilaku yang destruktif; Mengalami gangguan dalam perkembangan psikologis dan interaksi sosial; Pada anak yang lebih besar anak melakukan kekerasan pada temannya dan anak yang lebih kecil; Kesulitan untuk membina hubungan dengan orang lain; Kecemasan berat atu panik, depresi anak mengalami sakit fisik dan bermasalah di sekolah, Harga diri anak rendah; Abnormalitas atau distorsi mengenai pandangan terhadap seks; Gangguan personality; Kesulitan dalam membina hubungan dengan orang lain dalam hal seksualitas; mempunyai tendency untuk prostitusi; dan Mengalami masalah yang serius pada usia dewasa.

\section{E. Pembelajaran “Aku Anak yang Berani, Bisa Melindungi Diri Sendiri" di Yayasan Al-Hikmah Grobogan}

Materi pembelajaran di Yayasan Al-Hikmah Grobogan terkait dengan judul diatas sebagian besar diadopsi dari buku cerita tentang kejahatan seksual anak yang berjudul "aku anak berani, bisa melindungi diri sendiri" karya Watiek Ideo (2015) penerbit Gramedia. Proses pembelajaran pertema menggunakan metode cerita singkat yang dilengkapi dengan gambar kartun atau kadang guru mengkreasi sendiri alur ceritanya. Guru dituntut memahami hal-hal seputar tema yang disampaikan. Misalnya tentang perbedaan laki-laki dan perempuan, proses kelahiran bayi dll serta metode lain dalam pembelajaran agar siswa tidak bosan dan materi mudah difahami oleh siswa seperti pemutaran film atau dengan menggunakan role modeling sehingga efektif bagi pembelajaran anak. Pembelajaran "aku anak yang berani, bisa melindungi diri sendiri" di Yayasan Al-Hikmah Grobogan diterapkan pada Siswa Madrasah Ibtidaiyah (MI) oleh guru kelas masing-masing setiap seminggu sekali selama 3 bulan atau 10 kali pembelajaran/tatap muka serta 4 kali review materi bersama setelah shalat dhuhah berjamaah di mushollah. Namun sebelum dilakukan pembelajaran pada siswa, dilakukan pelatihan pembelajaran pada semua guru. Hal ini dimaksudkan agar guru memahami materi secara mendetail dan jelas sehingga guru dapat menjelaskan materi ketika ada pertanyaan dari siswa seputar kejahatan seksual anak serta dapat melakukan improvisasi pembelajaran sesuai kondisi kelas masing-masing. Tema materi pembelajaran terdiri dari sepuluh yaitu: kenapa berbeda, dari mana keluarnya adik bayi, pipis dimana, sentuhan apa nih, cerita nggak ya, ih takut ada hantu, siapa itu, khitan, mengapa tidak boleh, siapa yang bisa melindungiku. 


\section{Kenapa berbeda ${ }^{? 20}$}

Ilustrasi singkat: "sebuah cerita yang mengisahkan seorang anak perempuan kecil yang baru mempunyai adik laki-laki. Pada suatu hari adik lakilakinya ngompol dan ia melihat ibunya mengganti popok. Ketika melihat adiknya ganti popok, si anak perempuan ini merasa kaget, dalam hatinya berfikir "Kok ada sesuatu yang berbeda dari diri aku ya?" "Kok adikku mempunyai sesuatu yang tidak aku punyai ya". Nah., si anak perempuan ini terus bertanyatanya dan penasaran tentang apa yang di lihatnya itu. Kemudian Mamanya menjelaskan bahwa ini namanya kemaluan, disebut kemaluan karena kita semua akan malu kalau area pribadi ini dilihat orang lain. Jadi kita harus menutupnya. Lalu mengapa berbeda? Tuhan memang menciptakan manusia dua jenis, lakilaki dan perempuan". Dalam materi ini guru dapat menjelaskan perbedaan lakilaki dan perempuan dari sisi biologis. Guru juga dapat menjelaskan perbedaan lain yang diciptakan oleh Allah yang saling berlawanan/berpasangan, yang mempunyai fungsi saling melengkapi dan semuanya mempunyai manfaat yang sangat besar diantaranya perbedaan siang dan malam, matahari dan bulan, air dan api, gelap dan terang dan lain-lain. Perbedaan tersebut bukan untuk dimusuhi namun untuk disyukuri, karena perbedaan adalah rahmat tuhan, yang dapat menyempurnakan kehidupan. Dalam menjelaskan perbedaan tersebut diatas siswa harus diajak merasakan jika salah satu pasangan yang berlawanan tidak ada. Misalnya perbedaan siang dan malam, jika siang terus menerus apa yang terjadi? jika malam terus menerus apa yang terjadi? siswa diminta menyebutkan secara bergantian.

Dalam menjelaskan kepada anak usia 4-8 tahun, belum dibutuhkan penjelasan tentang perbedaan laki-laki dan perempuan dari sisi kematangan seksual yaitu keluarnya sperma dari alat kelamin laki-laki dan menstruasi dari alat kelamin perempuan. Kenapa? Anak usia tersebut belum cukup di beri informasi tentang kematangan seks, jika disampaikan akan membuat anak kebingungan serta anak belum mengingat informasi yang mendetail. Pendidikan seks yang bisa dibicarakan pada anak usia pra sekolah adalah pengenalan identitas diri dan jenis kelamin, hubungan antara laki-laki dan perempuan, organ-organ reproduksi

${ }^{20}$ Watiek Ideo, Aku Anak yang Berani, Bisa Melindungi Diri Sendiri, Jakarta: Gramedia Pustaka Utama, 2014), h. 5 
dan fungsinya, bagaimana menjaga kesehatannya, serta keterampilan menghindarkan diri dari kejahatan seksual. ${ }^{21}$ Jika sudah cukup usia, anak perlu mendapatkan pemahaman pengetahuan mengenai haid bagi perempuan, atau mimpi basah bagi laki-laki. Tak terkecuali pengetahuan tentang penyakit akibat perilaku seksual seperti HIV/AIDS.Penyampaian pendidikan seks tersebut dilakukan secara wajar, jujur, sederhana serta menggunakan bahasa yang mereka pahami.

Pada anak usia 9 tahun keatas informasi tersebut dapat disampaik an namun dengan bahasa yang lugas, jelas. Misalnya perempuan jika badannya cepat besar, dapat dicontohkan dengan nama temannya/kakak kelasnya/ tetangganya, yang sudah mengalami menstruasi yaitu alat kelaminnya akan mengeluarkan darah tapi tidak sakit, maka berarti anak perempuan tersebut sudah remaja/baligh, jika perempuan tersebut sudah baligh maka dia mempunyai kewajiban shalat 5 waktu dalam sehari dan puasa ramadhan. Siswa juga diajarkan hal-hal yang perlu dilakukan jika menstruasi yaitu memberitahu ibunya, jika siswa kurang dekat dengan ibunya/ibunya meninggal/bekerja menjadi TKW, anak dapat memberitahu guru perempuan disekolah yang dianggap nyaman oleh anak serta melakukan hal-hal yang boleh dilakukan dan tidak serta dampak yang akan dihadapi oleh anak jika melakukan hubungan seksual atau pernikahan pada usia yang sangat muda dibawah 17 tahun.

\section{Dari mana asalnya adik bayi?}

Dalam materi ini menceritakan bahwa seorang anak berusia 4 tahun bertanya kepada ibunya. "Adik bayi keluar dari mana? Ibunya kemudian menjelaskan bahwa kemarin perut ibu besar, itu berarti di dalam perut ibu terdapat adik bayi. Sebelum menjelaskan kepada siswa, guru dapat menanyakan kepada siswanya "adik bayi keluarnya dari mana ya?" apakah dibeli di pasar? atau keluar dari bantal atau keluar lewat perut ibunya? coba siapa yang mempunyai adik bayi? adik bayinya keluar dari mana?". Dengan pertanyaanpertanyaan tersebut guru dapat menanggapi jawaban dari siswa dan dapat menanyakan kembali. Misalnya jawaban siswa "keluar lewat perut ibunya", guru dapat menanyakan kembali "dari perut ibu lewat mana ya?' apa lewat "udel bodong" atau lewat anus/tempat BAB? guru dapat menjelaskan tentang

${ }^{21}$ Tabloid Nakita, http://www.nakita.com, diakses 24 Pebruari 2017.

${ }^{22}$ Watiek Ideo, Aku Anak yang Berani ...., h. 45. 
Bagaimana proses terjadinya kehamilan? Apa yang dirasakan oleh ibu ketika adik bayi didalam perut ibunya? Apa yang terjadi dengan adik bayi ketika dalam perut ibunya? Ketika sudah cukup usia adik bayi dalam perut ibu, apa yang terjadi? Bagaimana adik bayi keluar dari perut ibu? Apa itu caesar dan normal? Mengapa kita harus sayang pada ibu?

\section{Khitan, sakit nggak ya? ${ }^{23}$}

Pada tema ini guru menjelaskan pada siswa tentang khitan atau dalam bahasa jawa namanya sunat. Dalam materi ini guru dapat menanyakan dan menjelaskan kepada siswa tentang, Siapa yang mempunyai kakak atau tetangga yang sudah khitan? Kira-kira dikhitan itu rasanya seperti apa? Bagaimana proses khitan? Yang di khitan laki-laki atau perempuan? Kenapa laki-laki yang beragama islam wajib dikhitan? Apa ya manfaat khitan bagi laki-laki?

\section{Cerita nggak yah? ${ }^{24}$}

Menceritakan tentang seorang anak perempuan yang mengalami kejahatan seksual dari orang terdekatnya yaitu pamannya sendiri dalam bentuk perkosaan. Dalam menjelaskan materi ini, diharapkan guru dapat memotivasi anak untuk menceritakan setiap kejadian dalam keseharian kepada orang tuanya, jika orang tuanya kurang respon dengan ceritanya baik yang menyenangkan, apalagi yang menyedihkan, yang membuat dia menangis karena tersakiti maka siswa didorong untuk menceritakan kepada guru yang dianggap dekat dengannya. Orang tua atau guru tidak akan marah kepadanya bahkan akan menolongnya jika dia mengalami masalah. Selain itu anak dilatih komunikatif, dapat menceritakan kejadian dalam hidupnya, tidak dengan menyembunyikannya karena dapat merugikan dirinya diantaranya adalah kesedihan yang berlarut serta jika kejahatan seksual terjadi pada anak, maka kejahatan tersebut akan terus berulang sampai tanpa batas bahkan sampai anak dewasa.

\section{Pipis di mana? ${ }^{25}$}

Tema ini menceritakan anak lelaki yang pipis sembarangan. Dalam cerita ini guru dapat menjelaskan tentang pentingnya menjaga kebersihan tubuh
${ }^{23} \mathrm{Ibid.}$. h. 73.
${ }^{24}$ Ibid., h. 83.
${ }^{25}$ Ibid., h. 15. 
terutama alat kelamin serta pentingnya menjaga aurat agar tidak diketahui orang lain sehingga tidak memberi kesempatan kepada orang lain mengetahui atau melihat alat kelamin yang dimiliki yang dapat memicu terjadinya kejahatan seksual pada anak. Bagi anak usia tujuh tahun keatas, setelah pipis diwajibkan untuk membersikan diri dengan benar agar tidak menimbulkan najis yang dapat mengganggu aktifitas shalatnya karena ketika seorang muslim mengerjakan shalat, maka dia harus bersih dalam arti suci badan dan pakean yang digunakan. Selain itu melatih anak untuk hidup bersih sebagaimana islam mengajarkan untuk selalu menjaga kebersihan.

\section{Apakah ada monster?}

Guru dapat mendorong anak meminta pada orang tuanya untuk tidur dengan tempat tidur tersendiri atau jika tidak memungkinkan tidur bersama saudaranya namun dengan selimut masing-masing. Selain itu anak diminta untuk memperhatikan keamanan kamar dengan cara mengunci kamar dari dalam ketika tidur atau berganti pakean. Hal ini dimaksudkan agar siapapun tidak bisa masuk kamar selain izin darinya serta upaya menghindarkan anak menjadi korban tindak kejahatan seksual ketika anak tertidur.

\section{Mengapa tidak boleh?26}

Dalam materi ini diharapkan guru dapat mendorong anak untuk menggunakan baju ketika dirumah atau ketika bermain dengan teman-temannya disekitar rumah karena dengan udara yang panas sebagian besar anak perempuan yang berusia 4 sampai 8 tahun ketika dirumah hanya menggunakan kaos dan celana dalam tanpa rok atau baju. Materi ini diharapkan dapat merubah cara berpakaian siswa ketika di rumah dan sekitarnya. Selain itu dijelaskan juga tentang cara berpakaian yang benar; Kapan boleh membuka baju? Dimana dibolehkan membuka baju? Siapa saja yang boleh melihat anggota tubuh kita yang private; Jika ada yang memaksa meminta anak membuka baju, apalagi celana dalam maka anak diajarkan untuk bisa menolaknya dan lansung melaporkan kepada orang tua atau guru atau anak diajari untuk bagaimana menghindar dari orang yang akan berniat jahat

\footnotetext{
${ }^{26}$ Ibid., h. 25.
} 


\section{Siapa itu? ${ }^{27}$}

Dalam tema ini menjelaskan tentang kewaspadaan anak terhadap orang yang tidak dikenal jika mereka mengajak pergi atau melakukan sesuatu atau memberi sesuatu yang menyenangkan bagi anak, bagaimana melakukan penolakan dan bagaimana menghindar.

\section{Sentuhan apa ini? ${ }^{28}$}

Guru dapat memberikan edukasi guna mengantisipasi terjadinya kejahatan seksual pada anak di manapun mereka berada. Edukasi yang penting untuk diberikan antara lain batasan anggota tubuh mana yang boleh dilihat oleh orang lain terutama lawan jenis, mana yang tidak boleh apalagi jika sampai diraba bahkan lebih, termasuk oleh orang yang dihormati seperti guru, atau kerabat bahkan oleh ayah atau ibu mereka sendiri. Selain itu guru dapat mengajarkan pada siswa meskipun dengan orang dekat misalnya orang tua, paman, kakek dll namun anak harus diajarkan untuk membatasi pelukan dan ciuman. Anak diminta untuk tidak memaksakan diri menerima sentuhan dari orang lain-baik berupa pelukan ataupun ciuman, meskipun itu adalah saudara Anda sendiri, jika dirinya tidak menyukainya meskipun orang tua memintanya dan memarahinya karena seringkali orang tua ingin anaknya kelihatan manis di depan sanak kerabat, sehingga menegur anak apabila ia menolak dipeluk oleh tante atau omnya. Dengan membebaskan anak menentukan pilihan, guru telah menanamkan dalam benak anak bahwa dia memiliki kendali atas tubuhnya sendiri.

\section{Siapa yang melindungiku? ${ }^{29}$}

Guru diharapkan dapat mengajari cara bersikap. Disampaikan kepada anak untuk mempercayai kata hatinya. Apabila ia merasa ada sesuatu yang tidak beres, maka segeralah lari menghindar atau mencari orang dewasa yang bisa dipercaya (guru, polisi, dan lain-lain). Katakan bahwa tidak apa-apa bila ia berlaku tidak sopan (berteriak, menjerit, menepis tangan seseorang, atau lari menjauh), apabila ia merasa terancam bahaya. Ajari pula si kecil untuk menolak

\footnotetext{
${ }^{27} \mathrm{Ibid.}$., h. 97.

${ }^{28}$ Ibid., h. 35.

${ }^{29} \mathrm{Ibid} ., \mathrm{h} .111$.
} 
pemberian apa pun dari orang yang tidak ia kenal. Ini termasuk makanan, minuman, mainan, dan (terutama) tumpangan untuk pulang ke rumah atau pergi ke suatu tempat.

\section{F. Hasil Pembelajaran “Aku Anak yang Berani, Bisa Melindungi Diri Sendiri"}

Pembelajaran "Aku Anak yang Berani, Bisa Melindungi Diri Sendiri" pada siswa MI di Yayasan al-Hikmah Grobogan menghasilkkan beberapa pemahaman bahwa anak-anak memahami sepuluh persoalan yang mendatangkan atau mengancam terjadinya kejahatan seksual. Pembelajaran dilakukan melalui Focus Group Discusion (FGD) pada perwakilan siswa masing-masing kelas yang berjumlah 15 anak. dari FGD didapatkan bahwa siswa dapat menjelaskan pertanyaan-pertanyaan seputar dirinya secara biologis, bagaimana menjaga diri agar terhindar dari kejahatan seksual melalui 10 tema yaitu kenapa berbeda, dari mana keluarnya adik bayi, pipis dimana, sentuhan apa nih, cerita nggak ya, ih takut ada hantu, siapa itu, khitan, mengapa tidak boleh, siapa yang bisa melindungiku. Setelah pembelajaran "aku anak yang berani, bisa melindungi diri sendiri" berakhir dilakukan khitan massal di Yayasan al-Hikmah Grobogan pada 13 Juni 2015, dari home visit peneliti pada siswa yang mengikuti khitan (perwakilan kelas 1 sampai kelas 4 yang berjumlah empat siswa) menghasilkan bahwa empat siswa cukup memahami tema khitan dan pipis dimana. hal itu terungkap dari permintaan peneliti untuk memperlihatkan alat kelaminnya apakah sudah sembuh atau belum usai dikhitan namun semua anak menolak dengan alasan malu, karena kemaluan tidak boleh diperlihatkan kepada orang lain kecuali darurat. Menurut orang tua siswa, anak menolak jika ada anggota keluarga yang ingin melihat lansung alat kelamin yang baru di khitan kecuali kedua orang tuanya.

Ketika melakukan home visit pada siswa sekolah lain yang tidak melakukan pembelajaran "aku anak yang berani, bisa melindungi diri sendiri" siswa tidak menolak ketika peneliti memintanya untuk memperlihatkan alat kelaminnya usai khitan. Melalui observasi, peneliti mencoba melihat bagaimana penerapan tema "siapa itu" dengan cara secara sengaja meminta seorang ibu yang tidak dikenal siswa ${ }^{30}$ dengan memberikan permen dan makanan ringan yang menggoda

${ }^{30} \mathrm{Cindy}$, siswa kelas $2 \mathrm{MI}$, berumur 8 tahun, rumahnya 500 meter dari sekolah MI. 
namun dengan mengajak siswa untuk naik motornya. Namun siswa yang bernama Cindy menolak pemberian ibu tersebut dan lansung pergi meninggalkan ibu yang tidak dikenalnya.

\section{G. Upaya Mengatasi kejahatan Seksual Anak Melalui Pembelajaran "Aku Anak Berani melindungi Diri Sendiri"}

Pembelajaran "Aku Anak Berani melindungi Diri Sendiri" merupakan salah satu metode literasi kekerasandan kejahatan seksual pada anak. Tujuan pembelajaran ini adalah melatih pemahaman, dan kepkaan anak atas perilakuperilaku yang menjadi faktor resiko kejahatan seksual pada anak. Pemahaman yang ditanamkan pada anak usia sekolah adalah mengenai organ tubuh mereka dan dapat pula dilanjutkan dengan pengenalan organ tubuh internal. Tidak ada cara instan untuk mengajarkan seks pada anak kecuali melakukannya setahap demi setahap sejak dini. Kita dapat mengajarkan anak mulai dari hal yang sederhana, dan menjadikannya sebagai satu kebiasaan sehari-hari. menanamkan pengertian pada anak sama halnya menanamkan pengertian tentang agama. Pengenalan seks pada anak dapat dimulai dari pengenalan mengenai anatomi tubuh. Kemudian meningkat pada pendidikan mengenai cara berkembangbiak makhluk hidup, yakni pada manusia dan binatang. Orang tua dapat memberi tahu apa saja dampak-dampak yang akan diterima bila anak begini atau begitu. Salah satu cara menyampaikan pendidikan seksual pada anak dapat dimulai dengan mengajari mereka membersihkan alat kelaminnya sendiri. Mana yang boleh disentuh ataupun tidak, serta sepuluh langkah yang telah diajarkan dalam pembelajaran aku Anak Berani Melindungi Diri Sendiri. Pendidikan ini pun secara tidak langsung dapat mengajarkan anak untuk tidak sembarangan mengizinkan orang lain memasuki wilayah tersebut.

Pengenalan seks pada anak dapat dimulai dari pengenalan mengenai anatomi tubuh. Kemudian meningkat pada pendidikan mengenai cara berkembang biak makhluk hidup, misalnya pada manusia. Sehingga orang tua dapat memberikan penjelasan mengenai dampak-dampak yang akan diterima bila anak sudah melakukan hal-hal yang menyimpangnya. Cara menyampaikan pendidikan seksual itu pun tidak boleh terlalu vulgar, karena justru akan berdampak negatif pada anak. Di sini orang tua sebaiknya melihat faktor usia. Artinya ketika akan mengajarkan anak mengenai pendidikan seks, lihat sasaran yang dituju. Karena ketika anak sudah diajarkan mengenai seks, anak akan 
kristis dan ingin tahu tentang segala hal. Jika menunda memberikan pendidikan seks pada saat anak mulai memasuki usia remaja, maka itu sudah terlambat. Karena di zaman di mana informasi mudah didapat dari Internet dan teman sebaya, maka saat anak usia remaja mereka telah mengetahui lebih banyak tentang seks dan kemungkinan besar dari sudut pandang yang salah. Cara yang dapat digunakan mengenalkan tubuh dan ciri-ciri tubuh antara lain melalui media gambar atau poster, lagu dan permainan. Pemahaman pendidikan seks di usia dini ini diharapkan anak agar anak dapat memperoleh informasi yang tepat mengenai seks. ${ }^{31} \mathrm{Hal}$ ini dikarenakan adanya media lain yang dapat mengajari anak mengenai pendidikan seks ini, yaitu media informasi. Sehingga anak dapat memperoleh informasi yang tidak tepat dari media massa terutama tayangan televisi yang kurang mendidik.

Berdasarkan hasil belajar tersebut diperoleh pemahaman yang meningkat dari yang masih belum memahami wilayah-wilayah resiko kejahatan, menjadi memahami wilayah-wilayah resiko kejahatan. Anak-anak cenderung memberikan respon penolakan dan mudah tidak percaya kepada orang asing yang baru dikenalnya. Pengertian inilah yang menjadi bagian penting dalam penyelenggaraan melek kejahatan seksual pada anak. Anak akan mudah melakukan proteksi terhadap dirinya tanpa diminta dan disuruh.

\section{H. Kesimpulan}

Kejahatan seksual terus terjadi di sekitar kita, yang memprihatinkan sebagian besar kejahatan seksual terhadap anak itu justru terjadi di tempat-tempat yang seharusnya menjadi tempat teraman bagi anak yaitu rumah, sekolah dan lain-lain. Dengan pelaku orang terdekat anak yaitu orang tua, saudara, paman, guru, pengasuh, tetangga dan lain-lain. Pelaku kejahatan seksual biasanya orangorang yang pernah mengalami kejahatan seksual di masa kecil. Korban berpotensi menjadi pelaku kejahatan saat mereka mengalami trauma berkepanjangan dan tak ditangani psikolog. Minimnya pendidikan kesehatan reproduksi, seksualitas dan kurangnya pemahaman religiusitas serta penyalahgunaan teknologi informasi seperti maraknya pornografi di internet mendorong

\footnotetext{
${ }^{31}$ Lestari Basoeki, Child Abuse dan Dampaknya terhadap Kesehatan (Yogyakarta: Pustaka Pelajar, 1999), h. 43; Romli Atmasasmita, Kejahatan Kesusilaan dan Pelecehan Seksual dalam Perspektif Kriminologi dan Victimonolog (Yogyakarta: Pustaka Pelajar, 1995), h. 51.
} 
banyaknya kejahatan seksual di Indonesia. Salah satu upaya dalam mengantisipasi kejahatan seksual tersebut adalah melalui pembelajaran "aku anak yang berani, bisa melindungi diri sendiri" yang dilakukan oleh Yayasan alHikmah oleh guru kelas masing-masing dan dilakukan seminggu sekali selama tiga bulan dapat memberikan pengetahuan pada siswa dalam mengantisipasi kejahatan seksual anak.[]

\section{Daftar Pustaka}

A. Husain S. \& Canwell. D.P. "Physical and Sexual Abuse of Children". Chapter 6. Special Problem in Fundamental of Child and Addoscent Psychopathology, American Psychiatric Press inc. Washington D.C. 1991.

Atmasasmita, Romli, Kejahatan Kesusilaan dan Pelecehan Seksual Dalam Perspektif Kriminologi dan Victimonolog, Yogyakarta: Pustaka Pelajar, 1995.

Basoeki, Lestari, Child Abuse dan Dampaknya terhadap Kesehatan, Yogyakarta: Pustaka Pelajar, 1999.

Cindy, informan penelitian, siswa kelas 2 MI,berumur 8 tahun, rumahnya 500 meter dari sekolah $\mathrm{MI}$.

From, Eric, Akar Kekerasan, Yogyakarta: Pustaka Pelajar, 1997.

Harian Suara Merdeka, dalam www.suara merdeka, diakses 23 Maret 2016.

Hasanah, Hasyim, "Pemahaman Kesehatan Reproduksi bagi Perempuan: Sebuah Strategi Mencegah Berbagai Resiko masalah Kesehatan Reproduksi Remaja", SAWWA, Jurnal Studi Gender, Vol. 11, No. 2, 2016.

Heyman, Richard E. \& Amy MS. Slep, "Do Child Abuse and Intraparental Marriage and Violence Lead to Adultthood Family Violence?", Journal of Mirrage and Family, 4, hal. 867-870, dalam http://www.proquesr.com/ pqdauto, diakses 27 Januari 2017.

Ideo, Watiek, Aku Anak yang Berani, Bisa Melindungi Diri Sendiri, Jakarta: Gramedia Pustaka Utama, 2014.

Kaplan, H.I., Sadock, B.J., Grebb. J.A., 1994. Problem Related to Abuse or Neglect in Kaplan and Sadock's Synopsis of Psychiatry Behavior Sciences Clinical Psychiatry, USA: William \& Wilkins. Baltimore, 1994. 
Merdeka.com, "Peristiwa Kejahatan Seksual Anak", www.merdeka.com, diakses 19 Pebruari 2016.

Mulyadi, R., Kenali Rasa Cemas yang Tidak Rasional, 2003, hal 2, dalam www.sinarharapan.com, diakses 27 Januari 2017.

Nadia, A., "Penganiayaan Terhadap Anak dalam keluarga", Makalah Seminar Kekerasan Anak: Efek Psikis, Fisik, dan Tinjauan Agama, 13-19 September 2004.

Nailufar, Nibras Nada "Tersangka Pedofil di Facebook Cabuli 11 Anak, Termasuk Keponakannya" dalam http://megapolitan.kompas.com/read/ 2017/03/17/18003001/tersangka.pedofil.di.facebook.cabuli.11.anak.termas uk.keponakannya, diakses 23 April 2016.

"Cabuli Anak-anak, Pedagang Pasar Malam Berusia 60 Tahun Ditangkap", www.kompas.com, diakses 23 Maret 2016.

Nakita, Tabloid, http://www.nakita.com, 24 Pebruari 2017.

Obrak John, "Pedofilia di Jakarta International School-JIS termasuk Kejahatan Kemanusiaan", Kompasiana, dalam http://www.kompasiana.com/ yungobrak/pedofilia-di-jakartainternationalschool-jis-termasuk-kejahatankemanusiaan-2_54f79481a33311207e8b467c; diakses 15 April 2016.

Patients Who Report Childhood Sexual Abuse,Am.J. Phychiat, 1999.

Stucke, John, "Early Trauma Tied to Adult Problem", (Business New, online) dalam http://www.proquest.com/pqdauto,, diakses 21 Januari 2017.

Terr, Lenore C., "Too Scared to Cry: Psychic Trauma in Childhood", New York: Basic Books, 1990), https://www.goodreads.com/book/show/787568. Too_Scared_To_Cry, diakses 12 Januari 2017.

Terry and Belkin, Child Psycology, Newyork: McGraw-Hills, 1989.

Tower, Cynthia Crosson, Child Abuse and Neglect, USA: Mc.Graw Hill, 2002. 